\title{
LITERATUR REVIEW : PIJAT OKSITOSIN DAN AROMA TERAPI LAVENDER MENINGKATKAN PRODUKSI ASI
}

\author{
Tuti $^{1)}$ Melyana Nurul Widyawati ${ }^{2)}$ \\ E-mail address: tutibidan123@yahoo.co.id
}

\begin{abstract}
Breast Milk (ASI) is the best main food for babies. But only $27.5 \%$ of mothers in Indonesia succeeded in giving exclusive breastfeeding. Breast milk that does not come out on the first day of baby's life is one of the inhibiting factors for exclusive breastfeeding entertainment. This problem can be anticipated since pregnancy through lactation counseling. Efforts to overcome problems that cannot be done in postpartum mothers in addition to breast care are with oxytocin massage and Lavender aromatherapy. Oxytocin massage for 2-3 minutes and lavender aromatherapy is an effort that can help postpartum mothers increase milk production. Lavender contains Linalool. This substance produces effects on the central nervous system (hypothalamus) which can increase the formation of breast milk, so that it can encourage exclusive breastfeeding for newborns.

Literature This review aims to find out the benefits of Oxytocin and Lavender Aromatherapy to increase milk production in post partum mothers.

Journal searches were conducted electronically using several databases, namely: Science Direct, Pubmed and Google Scholar from 2008 to 2018. The key words were "Oxitocyn Massage," Aromatherapy Lavender "/ Lavender Aromatherapy" and "Breast Milk Productian". The criteria used are quantitative research, complete and complete instruments. The results of the study selected articles in national journals as many as: 8 research and international journals as many as 2 studies.

Complementary midwifery interventions in oxytocin massage along the spine (vertebrae) to the sixth-costae bone in the mother and lavender aromatherapy can be categorized as safe and effective enough in increasing breast milk production. Lavender oxytocin and aromatherapy massage can increase breast milk production

Keywords: Breastmilk production; lavender aromatherapy; oxytocin massage

${ }^{1)}$ Students of master study program, Poltekkes Kemenkes Semarang

${ }^{2)}$ Poltekkes Kemenkes Semarang
\end{abstract}

\section{Pendahuluan}

ASI mengandung berbagai zat yang dibutuhkandalam proses pertumbuhan, perkembangan bayi, kesehatan dan imunitas bayi. Air Susu Ibu ( ASI ) merupakan makanan pertama, utama dan terbaik bagi bayi yang bersifat alamiah. ASI yang diproduksi selama hari-hari pertama kelahiran, mengandung kolostrum yang dapat melindungi bayi dari penyakit.
Komponen penting untuk kelangsungan hidup bayi adalah dengan pemberian ASI sedinimungkin.(Lestari, et al., 2016) World Health Organization (WHO) dan United National Children,s Fund (UNICEF) merekomendasikan pemberian nutrisi yang optimal bagi bayi baru lahir melalui strategi global pemberian ASI eksklusif selama 6 bulan (WHO, 2009). America 
Academy of Pediatrics (AAP) merekomendasikan pemberian ASI eksklusif pada bayi selama minimal 6 bulan dan dapat dilanjutkan minimal sampai bayi berusia 12 bulan(Albertina, et al., 2015)

Proses Laktasi terjadi dibawah pengaruh berbagai kelenjar endokrin, terutama hormon-hormon hipofisis prolaktin dan oksitosin.Produksi dan sekresi ASI merupakan proses fisiologis dari laktasi, maka faktorfaktor yang berpengaruh pada proses laktasi antara lain posisi dan fiksasi bayi yang benar pada payudara serta frekuensi dan durasi menyusui, pengosongan pada payudara, nutrisi, keadaan ibu baik fisik maupun psikis serta keadaan payudara. Gangguan pada laktasi terjadi karena berbagai faktor diantaranya faktor bayi, ibu dan lingkungan.(Delima, et al., 2016)

Peningkatan kadar prolaktin dalam darah akan mencapai puncak pada 45 menit pertama setelah lahir dengan dirangsang oleh pemberian ASI sedini mungkin. Apabila ASI dikeluarkan atau dikosongkan secara menyeluruh maka akan meningkatkan produksi ASI menjadi lebih banyak. Pemberian ASI awal sampai bayi berumur 6 bulan dapat mengurangi $22 \%$ kematian bayi di bawah umur 28 hari(Jamilah, et al., 2013)

Hambatan pemberian ASI Eksklusif pada bayi baru lahir sering disebabkan karena ASI yang belum keluar dan berkurangnya produksi ASI, hal ini karena kurangnya rangsangan hormone prolactin dan hormone oksitosin yang sangat berperan dalam kelancaran produksi ASI..(Heni Setyowati, et al., 2015)

Pijat oksitosin merupakan salah satu solusi untuk mengatasi ketidaklancaran produksi ASI. Pijat oksitosin dilakukan pada sepanjang tulang belakang (vertebrae) sampai tulang costae kelima-keenam ibu akan merasa tenang, rileks, meningkatkan ambang rasa nyeri dan mencintai bayinya, sehingga dengan begitu hormone oksitosin keluar dan ASIpun cepat keluar. Tindakan pijat oksitosin ini memberikan sensasi rileks pada ibu dan melancarkan aliran saraf serta saluran ASI kedua payudara lancar (Lestari, et al., 2016)

\section{Gambar 1. Cara Pijat oksitosin}

\section{Pijat Oksitosin}

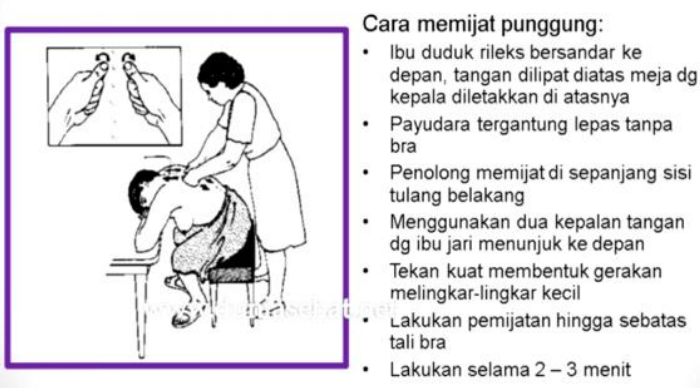

Sumber: (Roesli \& Yohmi, 2013)

Pijat oksitosin bermanfaat meningkatkan relaksasi dan tingkat kenyamanan ibu, sehingga memicu produksi hormon oksitosin dan mempengaruhi pengeluaran ASI. Efek pijat oksitosin adalah sel kelenjar payudara mensekresi ASI sehingga bayi mendapatkan ASI sesuai dengan kebutuhan dan berat badan bayi bertambah(Hamidah \& Shentya Fitriana, 2017)

Ibu post partum primipara yang melahirkan spontan pervaginam yang mendapatkan mendapatkan intervensi pemijatan punggung, yaitu pemijatan pada sepanjang tulang belakang sampai tulang costae kelima dan keenam akan merangsang hormone prolactin yang diproduksi oleh hipofise anterior dan 
oksitosin yang diproduksi oleh hipofise posterior, sehingga ASI dapat keluar dengan lancar. Setelah dilakukan pijat punggung dengan menggunakan minyak aromaterapi lavender Rerata kadar hormone prolactin dan oksitosin akan meningkat.(Ariani, et al., 2017)

Pada persalinan kala I yang lama akan menyebabkan ibu mengalami kelelahan,dan sekitar 85\%-95\% wanita melahirkan melaporkan rasa nyeri yang hebat selama kala II persalinan, nyeri bersalin juga dapat mempengaruhi ketegangan emosi akibat rasa cemas, sampai rasa takut (Dewi, et al., 2017)

Penggunaan minyak esensial aroma therapy lavender dapat membantu ibu untuk relaksasi dan kenyamanan sehingga diharapkan produksi ASI dapat meningkat. Lavender merupakan salah satu minyak esensial yang popular dan secara luas digunakan dalam bidang kesehatan klinis khususnya mengatasi permasalahan psikosomatik dalam ginekologi (Matsumoto, 2013).Kandungan aktif utama pada minyak lavender yang berperan pada efek anti cemas (relaksasi) adalah linalool dan linalyl acetat. (Jamilah, et al., 2013)

Dalam penelitian yang dilakukan Wei Chien, dkk tahun 2011 menyatakan bahwa perubahan yang signifikan dalam kualitas tidur terjadi pada wanita yang menghirup aromaterapi lavender. Sedangkan penelitian yang dilakukan oleh Koulivand, dkk tahun 2013 menyatakan bahwa efek relaksasi pada sistem syaraf pusat ditimbulkan jika menghirup aromaterapi lavender. Efek relaksasi pada system syaraf pusat membantu meningkatkan produksi hormone oksitosin yang berdampak terhadap meningkatnya produksi ASI karena Hypothalamus yang terdapat pada system saraf pusat berfungsi menghasilkan hormon oksitosin. (CS, et al., 2016)

Tujuan dari studi ini untuk melakukan review pada beberapa literature tentang pijat oksitosin dan aromaterapi lavender untuk meningkatkan produksi ASI. Hal ini diharapkan dapat diterapkan secara efektif pada pelayanan klinis dan menjadi rekomendasi intervensi kebidanan dalam melakukan asuhan kepada ibu post partum dengan permasalahan ASI belum keluar atau tidak lancar pada hari-hari pertama postpartum.

\section{Metode Penelitian}

Jenis Studi ini adalah metadata analisis dengan menggunakan tinjauan literature (Literatur review) yang menggali tentang manfaat pijat oksitosin dan aromaterapi lavender untuk meningkatkan produksi ASI.

Strategi yang digunakan dalam mencari artikel menggunakan bahasa Indonesia dan bahasa Inggris yang relevan dengan topik. Beberapa database digunakan untuk pencarian secara elektronik antara lain Sience Direct, Pubmed dan Google Scholar dari tahun 2008 sampai tahun 2018.

Keyword yang digunakan adalah pijat oksitocin/ oxytocin massage, aromaterapi lavender/ Lavender aromatherapy, Produksi Air Susu Ibu/ Breast milk production. Pencarian menggunakan database dengan keyword diperoleh hasil 10 artikel yang membahas manfaat pijat oksitosin dan aromaterapi lavender untuk meningkatkan produksi ASI. Artikel yang fulltext dan abstrak yang diperoleh di review untuk memilih artikel yang sesuai dengan kriteria inklusi, 10 artikel yang sesuai disajikan 
dalam bentuk narasi.. Penulisan artikel ilmiah ini menggunakan penulisan daftar pustaka Harvard.

\section{HASIL DAN PEMBAHASAN}

Artikel pertama merupakan penelitian yang dilakukan oleh Meity Albertina di Samarinda, Kalimantan Timur. Dengan Judul "Hubungan Pijat Oksitosin dengan kelancaran Produksi ASI pada Ibu Postpartum Seksio Sesarea hari ke 2-3". Rancangan penelitian menggunakan cross sectional. Jumlah sampel dalam penelitian ini adalah 48 responden. Teknik pengambilan sampel menggunakan total Sampling. Uji Statistik dalam penelitian ini adalah Uji Chi Square. Hasil penelitian menyatakan adanya hubungan yang signifikan antara pijat oksitosin dengan kelancaran produksi ASI (nilai X2 hitung $=8,765>\mathrm{X} 2$ tabel 3,841, Pvalue $=0,003)$. (Albertina, et al., 2015)

Artikel ke dua penelitian yang dilakukan oleh Dewi Ariani di Malang Raya, dengan judul "Pengaruh Relaktasi Suplementer Dikombinasikan dengan Pijat Oksitosin dan Aromaterapi Lavender terhadap Peningkatan Berat Badan Bayi di Malang Raya" Populasi dalam penelitian ini adalah ibu yang pernah menyusui dan memiliki masalah dalam menyusui (ASI kurang, bemberian ASi dikombinasi dengan susu formula dan pernah berhenti menyusu). Sampel dalam penelitian ini dibagi 4 kelompok yaitu relaktasi suplementer, relaktasi suplementer dan pijat oksitosin, relaktasi suplementer dan aromaterapi lavender dan relaktasi suplementer kombinasi aromaterapi lavender dengan pijat oksitosin.

Variabel yang diukur adalah Peningkatan berat badan bayi. Desain penelitian yang digunakan adalah quasi eksperimental atau rancangan penelitian eksperimensemu dengan Randomized Pre dan Post Test Only Control Group Design. Hasil penelitian ini adalah Hasil analisis pada variable peningkatan berat badan bayi tidak menunjukan perbedaan yang signifikan antar semua kelompok. Kesimpulan dari penelitian ini adalah Relaktasi suplementer metode kombinasi memberikan hasil yang terbaik.(Ariani, et al., 2017)

Artikel penelitian ketiga penelitian dilakukan oleh Adinda Putri Sari Dewi di puskesmas rowokele, Kabupaten Kebumen. Dengan judul “ Kombinasi Pijat Punggung dan Endorphin Terhadap Produksi ASI pada Ibu Postpartum" Jenis Penelitian ini menggunakan Quasi Eksperimen, dengan menggunakan rancangan post test only design with control group. Ibu postpartum di wilayah Rowokele menjadi populasi target dalam penelitian ini.

Jumlah sampel sebanyak 22 sampel untuk setiap kelompok ( intervensi dan control ) teknik pengambilan sampel dengan consecutive sampling. Analisis bivariate menggunakan Chi Square dengan tingkat signifikan $\mathrm{p}<0,05$. Hasil penelitian ini adalah Kelompok pijat punggung dan kelompok control terdapat perbedaan kelancaran produksi ASI.Peluang kelancaran produksi ASI sebesar 0,2 pada ibu yang mendapat intervensi pijat punggung dan pijat endorphin dibanding kelompok control. (Dewi, et al., 2017)

Artikel penelitian ke empat dilakukan di di rawat inap departemen Obstetri (Bangsal pasca melahirkan ) dan Pediatri di rumah sakit pendidikan 
perawat tersier di India tengah dari Juli 2011 hingga Oktober 2012, Judul penelitian ini adalah "Effect of back Massage on Lactation among Postnatal Mother" Metode Penelitian dengan menggunakan Quasi Eksperiment, dengan jumlah sampel kelompok intervensi sebanyak 100 sampel dan kelompok control 120 sampel. Diperoleh hasil, adanya kenaikan berat badan bayi secara signifikan, Jumlah buang air besar dan buang air kecil lebih banyak, durasi tidur bayi lebih lama setelah menyusu. Kesimpulan penelitian ini adalah Pijat efektif dalam meningkatkan laktasi.(U \& DS, 2013)

Penelitian ke lima dilakukan di Unit Kebidanan dan Ginekologi di Iran, dengan judul penelitian "Effect of lavender scent inhalation on prevention of stress, anxiety and depression in the postpartum period"Sampel sebanyak 140 responden (kelompok intervensi dan kelompok control). Analisa data menggunakan Mann whitney, analisis varian menggunakan ANOVA dan tes post hok. Hasil penelitian menunjukkan bahwa rata-rata stres, kecemasan, dan depresi pada titik waktu 2 minggu $(P=0,012, P<0,0001$, dan $\mathrm{P}=0,003$, masing-masing) dan stres, kecemasan, dan skor depresi pada titik waktu 1 bulan $(\mathrm{P}<0,0001)$ dan 3 bulan setelah melahirkan ( $P$ $<0,0001)$ secara signifikan lebih rendah pada kelompok intervensi dibandingkandengan kelompok control(Kianpour, et al., 2016).

Penelitian ke enam di lakukan di Semarang dengan Judul "Aromatherapy Massage As An Alternative In Reducing Cortisol Level And Enhancing Breastmilk Production On Primiparous Postpartum Women In Semarang". Metode penelitian menggunakan Quasi Eksperimen, dengan jumlah sempel sebanyak 44 responden (kelompok intervensi dan kelompok control). Hasil : Produksi ASI mengalami perbedaan yang signifikan diantara empat kelompok ( $\mathrm{p}$ value $=0,000)$, Tingkat kortisol dipengaruhi oleh pijat, aromaterapi dan pijat aromaterapi. (p-value $=0,004, p$ value $=0,001, p$-value $=0,000 .(\mathrm{CS}$, et al., 2016)

Penelitian ke tujuh dilakukan di Puskesmas Plus Mandiangin dengan Judul "Pengaruh Pijat Oksitosin terhadap peningkatan produksi ASI ibu menyusui di Puskesmas Plus Mandiangin". Desain penelitian mengguanakan Quasi Eksperimen, dengan pendekatan pretest dan post test. Jumlah sampel dalam penelitian ini sebanyak 21 sampel dengan teknik total sampling.

Hasil penelitian ini adalah, ada efek pijat oksitosin untuk meningkatkan produksi ASI dengan $p$ value 0,000.(Delima, et al., 2016)

Penelitian ke delapan yang dilakukan di Kediri, dengan Judul penelitian "Produksi Asi Ibu Dengan IntervensiAcupresure Point For Lactation Dan Pijat Oksitosin. Desain penelitian menggunakan Quasi Eksperimen dengan rancangan prepost test design with control grup. Jumlah sempel sebanyak 27 ibu post partum primipara, dibagi menjadi 3 kelompok dengan intervensi Acupresure Point For Lactation, intervensi pijat oksitosin dan kelompok control. Hasil penelitian menunjukan hasil analisa comfort p:0,035, ibu yang mendapatkan Acupresure Point For Lactation lebih merasakan kenyamanan dan produksi ASI lebih banyak dibandingkan ibu yang mendapat intervensi pijat oksitosin, dan ibu yang mendapat intervensi pijat 
oksitosin ASInya lebih banyak dibandingkan kelompok control(Rahayu, et al., 2015)

$$
\text { Penelitian }
$$
dilakukan di kota Tanjung Pinang, dengan judul "Pijat Oksitosin dan Perawatan Payudara terhadap kelancaran pengeluaran ASI pada Ibu Nifas" Metode penelitian menggunakan pre eksperimen dengan rancangan one group pretest-posttest. Jumlah sampel dalam penelitian ini sebanyak 36 sampel, dengan teknik pengambilan sampel secara non random dengan cara Consecutive sampling. Analisis data menggunakan Uji Wilcoxon Test. Hasil penelitian menunjukan perawatan payudara mempunyai nilai $p$ value $<\alpha(0,001$ $<0,05)$, dan pijat oksitosin mempunyai nilai $p$ value 0,000 dengan kesimpulan pijat oksitosin lebih efektif dalam meningkatkan produksi ASI disbanding perawatan payudara.(Seribu \& Wasis pujiati, 2015)

Penelitian ke sepuluh dilakukan di Kabupaten Dompu dengan judul penelitian "Pengaruh Pijat Oksitosin terhadap kelancaran Produksi Kolostrum pada ibu postpartum di Puskesmas Rasa Bou, Kabupaten Dompu". Metode penelitian menggunakan Quasi Eksperimental dengan pendekatan control group design. Jumlah sampel sebanyak 30 responden. Teknik pengambilan sampel menggunakan accidental Sampling. Analisa data menggunakan Uji Man withney. Hasil penelitian ini adalah ada pengaruh pijat oksitosin terhadap kelancaran produksi kolostrum.(Lestari, et al., 2016)

Penelitian yang dilakukan oleh penulis di puskesmas Rawalo dengan judul “ Peningkatan produksi ASI melalui kombinasi pijat oksitosin dan aromaterapi lavender" dengan responden ibu postpartum hari pertama, dan jumlah sempel sebanyak 2 sampel, dilakukan pada bulan juliagustus 2018, memperoleh hasil sebagai berikut:

Tabel 1. Hasil Observasi sebelum dilakukan kombinasi pijat oksitosin dan aromaterapi lavender

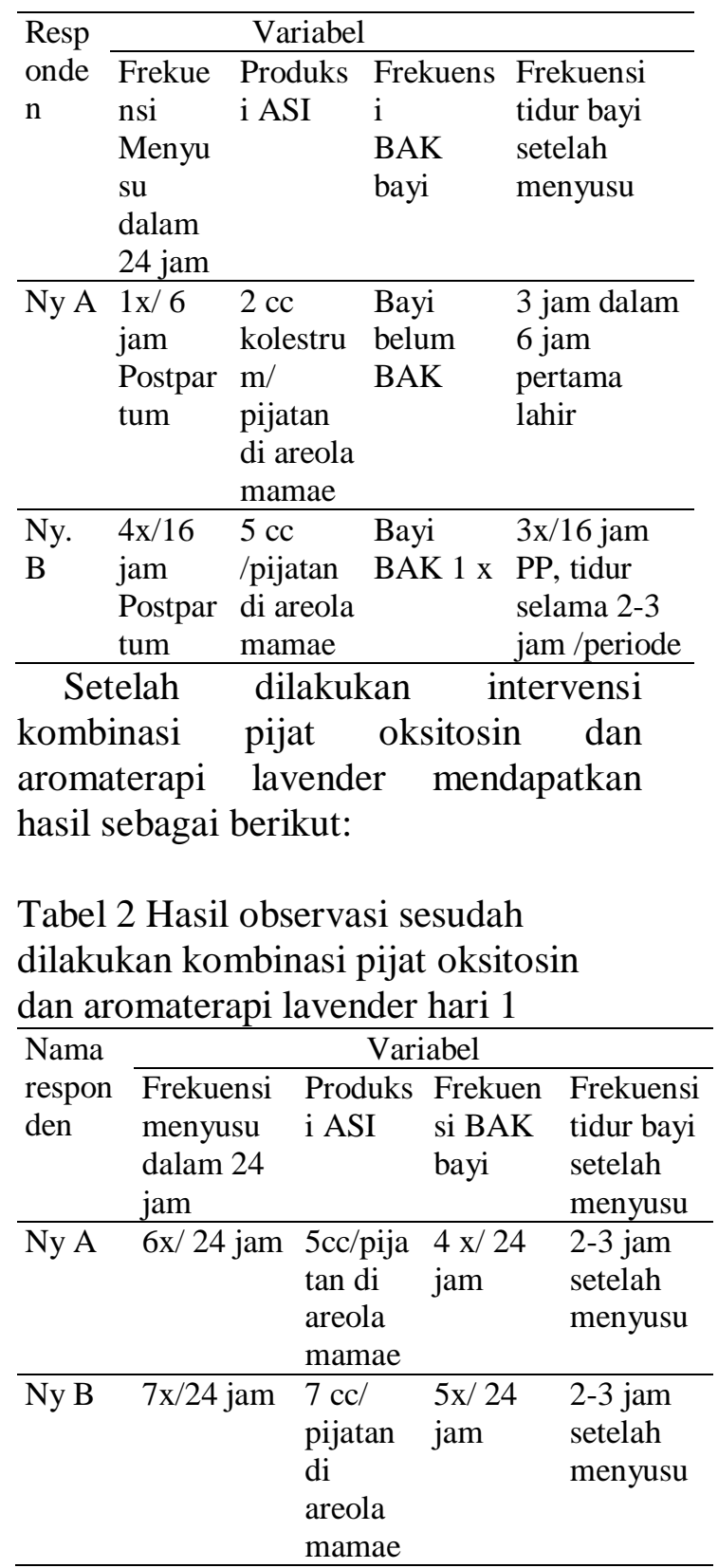


Tabel 3 Hasil Observasi sesudah dilakukan kombinasi pijat oksitosin dan aromaterapi lavender hari 2

\begin{tabular}{|c|c|c|c|c|}
\hline \multirow[b]{2}{*}{$\begin{array}{l}\text { Respo } \\
\text { nden }\end{array}$} & \multicolumn{4}{|c|}{ Variabel } \\
\hline & $\begin{array}{l}\text { Menyusu } \\
\text { bayi dalam } \\
24 \text { jam }\end{array}$ & $\begin{array}{l}\text { Produksi } \\
\text { ASI }\end{array}$ & $\begin{array}{l}\text { BAK } \\
\text { bayi }\end{array}$ & $\begin{array}{l}\text { Tidur } \\
\text { bayi } \\
\text { setelah } \\
\text { menyusu }\end{array}$ \\
\hline $\mathrm{Ny} A$ & $7 x / 24$ jam & $\begin{array}{l}10 \\
\text { cc/pijatan } \\
\text { di areola } \\
\text { mamae }\end{array}$ & $\begin{array}{l}5 \mathrm{x} / \\
24 \\
\text { jam }\end{array}$ & $\begin{array}{l}2-3 \text { jam } \\
\text { setelah } \\
\text { menyusu }\end{array}$ \\
\hline Ny B & $7 \mathrm{x} / 24 \mathrm{jam}$ & $\begin{array}{l}12 \mathrm{cc} / \\
\text { pijatan di } \\
\text { areola } \\
\text { mamae }\end{array}$ & $\begin{array}{l}5 x / 24 \\
\text { jam }\end{array}$ & $\begin{array}{l}2-3 \text { jam } \\
\text { setelah } \\
\text { menyusu }\end{array}$ \\
\hline
\end{tabular}

Dari sepuluh jurnal yang dipilih terdapat 8 penelitian tentang pijat oksitosin dimana 7 dari 8 penelitian tersebut menggunakan metode penelitian yang samayaitu Quasi Eksperimen. 2 jurnal tentang aromaterapy dan aromaterapi lavender,dan penelitian yang telah penulis lakukan,menyimpulkan bahwa pijat oksitosin dan aromaterapi lavender efektif meningkatkan produksi ASI. Pijat oksitosin adalah intervensi yang mudah dan gampang dilakukan dan juga aman bagi ibu. Intervensi ini dapat dilakukan oleh suami atau keluarga pasien, setelah dilatih oleh bidan/petugas kesehatan.

Kadar oksitosin pada ibu yang mendapat intervensi pijat punggung bagian belakang lebih tinggi dibandingkan ibu yang tidak mendapat intervensi. Peningkatan level oksitocin sebanyak $17 \%$ dari level basal oksitosin itu sendiri terjadi pada ibu yang mendapatkan pijat punggung. Oksitosin dapat meningkatkan produksi ASI dimana sifatnya sebagai pemicu/Let down reflek dan sebagai Prolaktin Releasing Hormon.(CS, et al., 2016)

$\begin{array}{lrr}\text { Pijat oksitosin } & \text { melalui } \\ \text { eurotransmitter akan } & \text { merangsang }\end{array}$ modulla oblongata dengan mengirim pesan hypothalamus di hipofise posterior, hal tersebut merangsang reflek oksitosin atau reflek let down untuk mensekresi hormone oksitosin ke dalam darah. Dengan diberikan pijat oksitosin akan lebih memperlancar produksi ASI pada ibu menyusui dan juga memberikan kenyamanan pada ibu.(Delima, et al., 2016)

Dengan pijat oksitosin kelenjar hipofise posterior dirangsang untuk memproduksi oksitosin. Oksitosin yang masuk ke sistim peredaran darah merangsang sel-sel mioepitel yang berada di sekeliling alveolus mammae dan duktus laktiferus berkontraksi. Selsel mioepitel yang berkontraksi merangsang alveolus mengeluarkan ASI melalui duktus Laktiferus ke sinus laktiferus. Saat bayi menghisap, ASI yang berada di dalam sinus mengalami tekanan yang menyebabkan ASI keluar ke mulut bayi. Gerakan ASi yang keluar dari sinus disebut Let Down. Pada saat yang sama hal itu juga merangsang kelenjar adenofise yang menyebabkan hormone prolactin masuk ke sistim peredaran darah, hal ini menyebabkan ASI di produksi oleh sel-sel acinus dalam alveolus (prolaktin reflek) (Jamilah, et al., 2013)

Kadar oksitosin yang tinggi pada ibu menyebabkan metabolism lemak dalam tubuh ibu meningkat yang menyebabkan terjadi Lipolisis dan akan terjadi gluconeogenesis yang menyebabkan peningkatan kadar glucose dalam darah termasuk pada ASI. Hal ini yang menyebabkan peningkatan berat badan pada bayi secara signifikan. Namun pada penelitian kedua menunjukan hasil tidak ada perbedaan yang signifikan pada berat badan bayi antar kelompok intervensi dan kelompok control. 
Berbeda pada penelitian ke empat yang menunjukan hasil adanya peningkatan berat badan, adanya peningkatan jumlah buang air besar dan buang air kecil, juga durasi tidur lebih lama setelah menyusu pada kelompok intervensi.(Ariani, et al., 2017)

Faktor yang mempengaruhi keberhasilan peningkatan berat badan bayi dipengaruhi antara lain, durasi menyusu, berat badan waktu lahir, parietas, status gizi ibu dan social ekonomi keluarga.

Ada banyak teknik untuk meningkatkan produksi ASI, seperti teknik marmet, pijat oketani, perawatan payudara, hipnotherapi, aromaterapi dan lain-lain, dan bisa dikombinasikan beberapa teknik untuk meningkatkan produksi ASI. Dari jurnal yang didapat pada penelitian ke delapan teknik Acupresure Point For Lactation memberikan dampak yang lebih baik terhadap produksi ASI dibanding teknik pijat oksitosin. Dan pada penelitian kesembilan didapat bahwa pijat oksitosin lebih efektif untuk meningkatkan produksi ASI dibanding dengan perawatan payudara.

Proses persalinan menyebabkan ibu kelelahan dan juga menimbulkan rasa bahagia bagi seorang ibu, sekaligus rasa khawatir dan cemas dalam merawat dan menyusui bayinya, sehingga dapat menghambat dalam proses pemberian ASI seawal mungkin. Pada ibu setelah melahirkan selain kelelahan fisik juga mengalami gangguan tidur (Kuswoyo, C, 2008).

Ibu yang mengalami stress fisik dan emosional dapat mengganggu reflek pengeluaran ASI dan hormone oksitosin. Hipotalamus-hipofisis adrenal mengatur adaptasi stress dengan memproduksi hormone kortisol dan endorphin. Jika kadar kortisol meningkat akan mempengaruhi produksi ASI.(Jamilah, et al., 2013)

Aromaterapi Lavender mengandung linalool dan linalyl acetate yang memberikan efek antidepresan dan asiolitik (Pande, 2013). Pemberian aromaterapi lavender melalui inhalasi akan merangsang saraf penciuman, dan direspon oleh hipotalamus untuk menstimulasi sistim limbic dan hipofisis anterior agar kelenjar adrenal mengurangi sekresi hormone ACTH dan hormone kortisol, aktifitas simpatis dan pelepasan asetilkolin dihambat, dan system parasimpatik meningkat. Sehingga dapat memberikan efek relaksasi, obat penenang dan meningkatkan mood(Jamilah, et al., 2013)

Pada penelitian ke lima, aromaterapi lavender juga efektif untuk mengurangi kecemasan dan stress pada ibu postpartum di Iran, dan juga untuk mencegah terjadinya depresi postpartum/ postpartum blues yang dapat mengganggu kepentingan ibu, bayi dan anggota keluarganya(Kianpour, et al., 2016)

\section{Simpulan}

Berdasarkan analisis yang penulis lakukan terhadap 10 jurnal yang relevan dan penelitian yang penulis lakukan dapat disimpulkan:Produksi ASI responden setelah dilakukan pijat oksitosin dan aroma terapi lavender terjadi peningkatan yang signifikan ditandai dengan kenaikan volume ASI setelah dilakukan pemijatan di areola mamae, peningkatan frekuensi BAK dan BAB bayi dan lama tidur bayi setelah menyusu, dan juga ada kenaikan berat badan bayi.

Terdapat berbagai macam metode untuk meningkatkan produksi ASI, dan 
dapat dikombinasikan dalam melakukan intervensi untuk mengatasi permasalahan ASI.

Aromaterapi lavender selain dapat meningkatkan produksi ASI juga bisa mengurangi kecemasan pada ibu postpartum dan mencegah terjadinya depresi postpartum.

Pijat Oksitosin dan Aromaterapi Lavender adalah intervensi yang mudah, gampang dilakukan, dan aman bagi ibu. Intervensi ini juga dapat dilakukan oleh suami/keluarga pasien setelah dilatih oleh bidan/tenaga kesehatan.

Saran yang dapat diberikan adalah tenaga kesehatan dan masyarakat dapat menggunakan terapi kombinasi pijat oksitosin dan aroma terapi lavender sebagai salah satu alternatif metode relaksasi untuk meningkatkan dan memperlancar produksi ASI.

\section{Daftar Pustaka}

Albertina, M., Melly \& Rahmawati Shoufiah, 2015. Hubungan Pijat Oksitosin dengan Kelancaran produksi ASI pada Ibu Postpartum seksio sesarea hari ke 2-3. Jurnal Husada Mahakam, Volume III. No 9 Mei 2015, pp. 452-521.

Ariani, D., Nur Aini Retno Hastuti, Agnestia Naning Dian Lovita \& Ni Luh Putu Herli Mastuti, 2017. Pengaruh Relaktasi Suplementer Dikombinasikan dengan Pijat Oksitosin dan Aromaterapi. Journal of Issues in Midwifery, pp. 2549-6581.

Ariani, D., Nur Aini Retno Hastuti, Agnestia Naning Dian Lovita \& Ni Luh Putu Herli Mastuti, 2017. Pengaruh Relaktasi Suplementer Dikombinasikan dengan Pijat
Oksitosin dan Aromaterapi Lavender terhadap Peningkatan Berat Badan Bayi di malang raya. Journal of Issuees in Midwifery, Volume 1, pp. 76-81.

CS, A., Hadi \& Melyana Nurul Widyawati, 2016. Aromatherapy Massage As An Alternative In Reducing Cortisol Level And Enhancing Breastmilk Production On Primiparos Postpartum Women In Semarang.

Delima, M., Gina Zulfia Arni \& Ernalinda Rosya, 2016. Pengaruh Pijat Oksitosin Terhadap Peningkatan Produksi ASI Ibu Menyusui di Puskesmas Plus Mandiangin. JURNAL IPTEKS TERAPAN, pp. 2460-5611.

Dewi, A. P. S., Eni Indrayani \& Rina Khanifah, 2017. Kombinasi Pijat Punggung dan Endorphin terhadap Produksi ASI pada ibu Post Partum. Jurnal Ilmiah Kesehatan Keperawatan, Volume 13, No 2.

Hamidah \& Shentya Fitriana, 2017. Hipnobreasfeeding dan Pijat Oksitosin berpengaruh terhadap pengeluaran Kolostrum pada ibu post partum. Jurnal Ilmu dan Teknologi Kesehatan, Volume 5 Nomor 1, pp. 35-42.

Heni Setyowati, Ari Andayani \& Widayati, 2015. Perbedaan Produksi ASI pada Ibu Post Partum setelah pemberian Pijat Oksitosin. Volume 10, p. Jurnal Keperawatan Soedirman.

Jamilah, Ari Suwondo, Sri Wahyuni \& Suhartono, 2013. Efektifitas Kombinasi Pijat Oksitosin Tehnik Effleurage dan Aromaterapi Rose terhadap Kadar Prolaktin Post Partum 
normal di Puskesmas Dawe Kudus Tahun 2013. Jurnal Ilmiah Bidan.

Kianpour, M., Akram Mansouri, Tayebeh Mehrabi \& Gholamreza asghari, 2016. Effect of Lavender Scent Inhalation On Prevention Of Stress, Anxiety and Depression In The Postpartum Period. Iranian Journal of Nursing and Midwifery Research, pp. 197-201.

Lestari, H., IGA Juliantari \& Sri Murniati, 2016. Pengaruh Pijat Oksitosin Terhadap Kelancaran Produksi Kolostrum pada ibu postpartum di Puskesmas Rasa Bou Kecamatan Huu Kabupaten Dompu. Prima, pp. 85-97.

Maryam Kianpour, Akram Mansouri, Tayebeh Mehrabi \& Gholamreza Asghari, 2016. Effect of lavender scent inhalation of prevention of stress, anxiety and depression in the postpartum period. Iranian Journal of Nursing and Midwifery research, MarApr.pp. 197-201.

Rahayu, D., Budi Santoso \& Esti Yunitasari, 2015. Produksi Asi Ibu dengan intervensi Acupresure Point for Lactation dan Pijat Oksitosin. Jurnal Ners, Volume 10 no.1, pp. 9-19.

Rahayuningsih, T., Ambar Mudigdo \& Bhisma Murti, 2016. Effect of Breast Care and Oxytocyn Massage on Breast Milk Production. Journal of Maternal and child Health, pp. 101-109.

Roesli, U. \& Yohmi, E., 2013. Manajemen Laktasi. Jakarta: IDAI.

Seribu, H. J. D. \& Wasis pujiati, 2015. Pijat Oksitosin dan Perawatan
Payudara terhadap kelancaran Pengeluaran ASI pada Ibu Nifas. MEDISAINS, Volume 13 No 1

Ummah, F., 2014. Pijat Oksitosin untuk mempercepat pengeluaran ASI pada ibu pasca salin normal di dusun Sono desa Ketanen kecamatan Panceng Gersik. Surya, Volume 02 No XVIII.

U, P. \& DS, G., 2013. Effect of Massage on Lactation Among Postnatal Mothers. International Journal of Medical Research and Review, p. Vol 1/Issue 1. 